\title{
Characteristics and Activity of Anti Quorum Sensing Bacillus spp. Isolated from Penaeus vannamei Shrimp Ponds
}

\author{
Iman Rusmana1*, Yuni Puji Hastuti2, Rizal Khoirun Alfisah1, Alina Akhdiya \\ 'Departement of Biology, Bogor Agricultural University, Jl. Agathis, Dramaga, Bogor, Indonesia \\ 2 Department of Aquaculture, Faculty of Fisheries and Marine Affairs, IPB University, Jl. Agathis, Dramaga Bogor, Indonesia \\ ${ }^{3}$ Indonesian Research Center for Angricultural Biotechnology and Genetic Resources, Department of Agriculture, Jl. Tentara Pelajar, \\ Cimanggu, Bogor Indonesia
}

ARTICLE INFO

\section{Article history:}

Received September 17, 2021

Received in revised form october 21, 2021

Accepted November 11, 2021

\section{KEYWORDS}

AHNPD,

Bacillus,

white shrimp,

anti-quorum sensing

\begin{abstract}
Certain strains of $\boldsymbol{V}$. parahaemolyticus carry a gene that encodes a toxin that causes Acute hepatopancreatic necrosis disease (AHPND) in P. vannamei. AHPND attacks shrimp post larvae within 20-30 days after stocking causing up to $100 \%$ mortality. The expression of these virulent genes is controlled by the quorum sensing system. This system is inhibited by an anti-quorum sensing (AQS) mechanism. Several Bacillus strains have AQS mechanism by producing AHLLactonase enzyme. Therefore, this study aimed to obtain Bacillus spp. having AQS activity for controlling AHPND. The study was conducted from isolation and selection of Bacillus isolates, as well as determination of AQS activity. From 22 samples consisting of shrimp intestines, water and pond sediment samples, a total of 151 isolates of Bacillus spp. were isolated. The screening test for AQS activity obtained 11 isolates that showed AQS activity on Cromobacterium violaceum. Determination of violacein pigment in liquid cultures of $C$. violaceum showed the index value of the pigment formation was between 0.025-0.166 and 0.026-0.567 at 24-hour and between 48 -hour incubations, respectively. The quantitative analysis of violacein production showed that there were six isolates of Bacillus could inhibit the pigment production more than $\mathbf{7 5 \%}$. The isolates were identified as Bacillus cereus (four isolates), Bacillus thuringiensis (one isolate), and Bacillus velezensis (one isolate), respectively. The molecular analysis had confirmed that the isolates have aiiA genes encoding AHL-lactonase enzyme. These Bacillus isolates have potential application for controlling AHNPD disease.
\end{abstract}

\section{Introduction}

Vannameishrimpisanexportcommodity of fishery products in Indonesia. Disease attack is the main problem of shrimp production. One of the bacterial pathogens causing vibriosis is Vibrio parahaemolyticus (Longyant et al. 2008; Sarjito et al. 2018). Certain strains of $V$. parahaemolyticus carry a gene encoding a toxin that causes acute hepatopancreatic necrosis disease (AHPND in vannamei shrimp (Tran et al. 2013). AHPND was first reported in southern China in 2010 and subsequently in Vietnam, Thailand, and Malaysia (FAO 2013). This disease has been endemic in several countries in Asia such as China, Vietnam, Philippines, Thailand, Malaysia, and Mexico (Han et al. 2015; de la Peña et al. 2015; Soto-Rodriguez

\footnotetext{
* Corresponding Author

E-mail Address: irusmana@apps.ipb.ac.id
}

et al. 2015). AHPND attacks on shrimp post larvae within 20-30 days after stocking and causes up to $100 \%$ mortality (De Schryver et al. 2014). The Global Aquaculture Alliance (GAA 2013) estimates the loss of Asian shrimp aquaculture farms at one billion USD.

AHPND is caused by the binary gene pirAvp/pirBvp found on a plasmid of $V$. parahaemolyticus (Tran et al. 2013; Han et al. 2015; Lee et al. 2015). The expression of these genes is controlled by quorum sensing system. Quorum sensing (QS) is induced by a signal molecule called an autoinducer (AI) (Defoirdt et al. 2004). The signal molecule is an acyl homoserine lactones (AHL) molecule (Vinoj et al. 2014). The expression of this virulence factor gene can be inhibited by an antiquorum sensing (AQS) mechanism. AQS can inhibit production of autoinducer enzymatic degradation (Natrah et al. 2014). A broad-spectrum autoinducer degrading enzyme is AHL lactonase enzyme encoded by the aiiA gene. The AHL autoinducer degradation 
process by this enzyme does not depend on the variation of the acyl group (Defoirdt et al. 2004).

Several Bacillus strains such as $B$. cereus, $B$. substilis, and $B$. thuringiensis have aiiA gene encoded AHL-Lactonase enzyme that can degrade the AHL autoinducer(Kalia2013).Thesebacteriacanbeisolated from the pond environment, and the digestive tract of shrimp. And the Bacillus isolates was able to degrade autoinducers and inhibit QS in V. parahemolyticus (Defoirdt et al. 2008; Cao et al. 2012; Romero et al. 2014; Vinoj et al. 2014; Novita et al. 2015; Yuniarti et al. 2015; Torres et al. 2018). Therefore, Bacillus AQS isolates have potential application in shrimp ponds to control AHPND disease (Chu et al. 2010; Delshad et al. 2018).

Controlling of AHPND disease caused by $V$. parahaemolyticus in vanamei shrimp culture in Indonesia by utilizing the AQS mechanism from Bacillus spp. still has not been done much. Therefore, this study was conducted to obtain Bacillus spp. AQS Isolates. The selected isolates that characterized showing AQS activity can be further developed as biocontrol agents of AHPND disease in shrimp aquacultures.

\section{Materials and Methods}

\subsection{Isolation of Bacillus spp.}

Samples such as shrimp intestine, water and sediment shrimp ponds were collected from several shrimp ponds in Karawang (West Java), Tanggerang (Banten) and Lampung (Lampung), Indonesia. One gram of the samples was serially diluted in $9 \mathrm{ml}$ of $0.85 \% \mathrm{NaCl}$ solution. The suspension treated by heat shocking at $80^{\circ} \mathrm{C}$ for 5 minutes, then the appropriate dilutions were spread on 50\% SWC agar medium. Incubation was done aerobically at room temperature for 24 to 48 hours. Bacterial colonies grown in the agar plates were then purified to obtain a pure culture of the isolates.

\subsection{Selection of Bacillus Isolates Having AQS Activity}

Screening of pure culture of isolated Bacillus that had AQS activity was carried out by detecting anti quorum sensing activity using the disc diffusion method. The purified bacterial isolates were grown in Luria-Bertani broth (LB) medium on a shaker for 18 hours until the Optical Density (OD)600 nm reached 0.8-1.0 (equivalent to $1 \times 10^{-9} \mathrm{CFU} / \mathrm{mL}$ ). The culture was then centrifuged at $600 \mathrm{x} g$ for 10 minutes. The supernatant was filtered using a 0.22 um syringe filter. A total of $100 \mathrm{ul}$ of supernatant was dripped onto a sterile paper disk $(6 \mathrm{~mm})$ on the surface of Luria-
Bertani agar (LA) medium containing $1 \% \mathrm{C}$. violaceum (v/v). Incubated was done at $28^{\circ} \mathrm{C}$ for 24 hours. Sterile LB was used as a negative control. AQS activity of the isolates was indicated by the presence of a no purple zone around the paper disk. This zone was formed due to interference with QS C. violaceum by enzymes possessed by the test bacterial supernatant, so that the production of the purple pigment violaceum was inhibited (McLean et al. 1997). The diameter of the clear zone was measured from the outer edge of the paper disk to the edge of the colorless zone. The AHL degradation index is calculated by the following formula:

\section{AQS activity index $=$ Non-purple zone diameter Paper disk diameter}

\subsection{Determination of Inhibition Violacein Production by AQS Activity}

Determination of violacein Production Inhibition by AQS activity was conducted based on the method reported by Chaudari et al. (2014). As much as 300 ul of AQS bacterial supernatant was added to 30 $\mathrm{ml}$ of LB medium which was inoculated with $1 \% C$. violaceum $(\mathrm{v} / \mathrm{v})$. The cultures were incubated on a shaker incubator at room temperature for 24 hours and 48 hours. The violacein pigment was extracted from the cultures by centrifugation at $10,000 \mathrm{rpm}$ for 15 minutes. And the pellets were washed with $1.5 \mathrm{ml}$ DMSO and then centrifuged again at $10000 \mathrm{rpm}$ for 15 minutes. The pure culture of $C$. violaceum without addition of supernatant of the culture Bacillus isolates was used as a control. Violacein dissolved in DMSO was measured their absorbance at $585 \mathrm{~nm}$, while bacterial cells were measured at $600 \mathrm{~nm}$. The violacein unit index was measured by calculating the ratio of the absorbance at $585 \mathrm{~nm}$ and $600 \mathrm{~nm}$ (Chaudari et al. 2014). And the inhibition percentage of violacein was calculated form percentage ratio of violacein unit index of the treatment and the control.

\subsection{Identification of Bacterial Isolates Based on 165 rRNA Gene}

The selected bacterial isolates were identified based on the PCR product sequences of 16S rDNA gene. PCR amplification used primers of 63F and 1387R (Marchesi et al. 1998). The temperatures set up of the PCR machine were at $95^{\circ} \mathrm{C}$ for 5 minutes for pre-denaturation, $95^{\circ} \mathrm{C}$ for 1 minute for denaturation, $55^{\circ} \mathrm{C}$ for 1 minute for annealing at, $72^{\circ} \mathrm{C}$ for 1.5 minutes for elongation, and $72^{\circ} \mathrm{C}$ for 10 minutes for post elongation. The PCR was run for 30 cycles. The PCR products were electrophoresed on $1 \%$ agarose, then purified for sequencing. The sequence results of 
the PCR products were analyzed using the Basic Local Alignment Search Tool-Nucleotide (BLAST-N) in the the National Center for Biotechnology Information (NCBI) Gene Bank website [www.ncbi.nlm.nih.gov]. Phylogenetic analysis was done using the maximum likelihood method with 1,000x bootstraps of the MEGA X software.

\subsection{Detection of aiiA Gene Encoding AHL Lactonase of the Bacterial Isolates}

The selected bacterial isolates were grown on SWC media for 18 hours. The bacterial cells pellet was harvested by centrifugation at a speed of 6,000 $\mathrm{xg}$ for 10 minutes. The genomic DNA of the isolates was extracted using the Mericon DNA Bacteria Plus Kit (Qiagen). The presence of the aiiA genes was determined using primers pair of aiiAF and aiiAR (Dong et al. 2002). The amplification of the genes was set up at $94^{\circ} \mathrm{C}$ for 10 minutes for pre-denaturing, $94^{\circ} \mathrm{C}$ for 30 seconds for denaturation, $52^{\circ} \mathrm{C}$ for 30 seconds for annealing, $72^{\circ} \mathrm{C}$ for 1 minute for elongation at, and $72^{\circ} \mathrm{C}$ for $5 \mathrm{~min}$ for post elongation. The PCR was run for 30 cycles. The PCR product was purified using the QIA-quick PCR Purification Kit (Qiagen). Then the sequences of the PCR products were analyzed using the Basic Local Alignment Search Tool. -Nucleotide translation protein (BLAST-X) of the NCBI Gene Bank website. The phylogenetic tree of the amino acid sequences was constructed using the maximum likelihood method with 1,000x bootstraps of the MEGA X software.

\section{Results}

Isolation of Bacillus spp. bacteria was carried out from 22 samples consisting of samples of shrimp intestines, water and pond sediments of white shrimp (Penaeus vannamei) from several locations in Karawang (West Java), Tangerang (Banten), and Lampung (Lampung), Indonesia. A total of 151 isolates of Bacillus spp. Were successfully isolated from bacteria isolated from different sources (shrimp intestine, pond water and pond sediment). The results of the screening for AQS activity showed that 11 Bacillus isolates performed AQS activity on C. viloaceum consisting of 3 isolates from Karawang samples, 2 isolates from Tangerang samples, and 6 isolates from Lampung samples (Table 1). AQS activity was indicated by the presence of a nonpurple colony zone.

The results of the screening of ASQ activity using disk diffusion method to select isolates that had inhibitory activity on the production of violacein pigment by $C$. violaceum indicate that the culture supernatant of 11 Bacillus spp. isolates can inhibit the formation of violacein pigment indicated by the presence of a non-purple zone around paper discs (Table 2 and Figure 1). The non-purple zone index values the isolates were from 0.33 to 2.83 . The non-purple zone around the paper discs indicates the presence of AQS activity which inhibits the QS mechanism in $C$. violaceum. The three highest values of violacein pigment inhibition indexes were shown by the supernatants of LpgA01, LpgS03, and LpgS01 isolate (Table 2).

Quantitativedetermination of pigment production inhibition in liquid cultures of $C$. violaceum with the addition of culture supernatant of Bacillus spp. showed that the index value of violacein pigment formation was between 0.025-0.166 and 0.026-0.567 at 24 -and 48-hour incubations (Table 3 ). Some culture supernatants of the isolates also inhibited the growth

Table 1. Isolation results of Bacillus spp. which has anti-quorum sensing (AQS) activity isolated from samples of shrimp intestines, water, and pond sediments in several locations of shrimp ponds

\begin{tabular}{|c|c|c|c|c|c|}
\hline \multirow{2}{*}{ Pond location } & \multicolumn{2}{|c|}{ Sample } & \multirow{2}{*}{$\begin{array}{c}\text { Number } \\
\text { of Isolated } \\
\text { Bacillus }\end{array}$} & \multirow{2}{*}{$\begin{array}{c}\text { Number isolate } \\
\text { with } \\
\text { Positive AQS }\end{array}$} & \multirow[t]{2}{*}{ Isolate code } \\
\hline & Type & Number & & & \\
\hline \multirow[t]{3}{*}{ Karawang } & Shrimp intestine & 4 & 20 & 2 & KwgU01; KwgU02 \\
\hline & Pond water & 1 & 8 & - & \\
\hline & Pond sediment & 2 & 16 & 1 & KwgS01 \\
\hline \multirow[t]{3}{*}{ Tanggerang } & Shrimp intestine & 2 & 16 & 2 & TggU01; TggU02 \\
\hline & Pond water & 1 & 8 & - & \\
\hline & Pond sediment & 3 & 18 & - & \\
\hline \multirow[t]{3}{*}{ Lampung } & Shrimp intestine & 3 & 24 & 2 & LpgU01; LpgU02 \\
\hline & Pond water & 2 & 19 & 1 & LpgA01 \\
\hline & Pond sediment & 4 & 22 & 3 & $\begin{array}{l}\text { LpgS01; LpgS02; } \\
\text { LpgS03 }\end{array}$ \\
\hline Total & & 22 & 151 & 11 & \\
\hline
\end{tabular}


Table 2. Diameter of the non-purple zone of $C$. violaceum by addition culture supentants of Bacillus spp. isolated from samples of shrimp intestines, pond water and pond sediments in several locations of shrimp ponds

\begin{tabular}{lcc}
\hline Isolate code & $\begin{array}{c}\text { Diameter of Non-purple } \\
\text { zone }(\mathrm{mm})\end{array}$ & $\begin{array}{c}\text { Indexes of non- } \\
\text { purple zone }\end{array}$ \\
\hline LpgS01 & 16 & 1.67 \\
LpgS02 & 10 & 0.67 \\
LpgS03 & 18 & 2.00 \\
LpgU01 & 14 & 1.33 \\
LpgU02 & 8 & 0.33 \\
LpgA01 & 23 & 2.83 \\
TggU01 & 9 & 0.50 \\
TggU02 & 8 & 0.33 \\
KwgU02 & 13 & 1.17 \\
KwgS01 & 9 & 0.50 \\
KwgU01 & 12 & 1.00 \\
Control $(-)$ & 0 & 0.00 \\
\hline
\end{tabular}
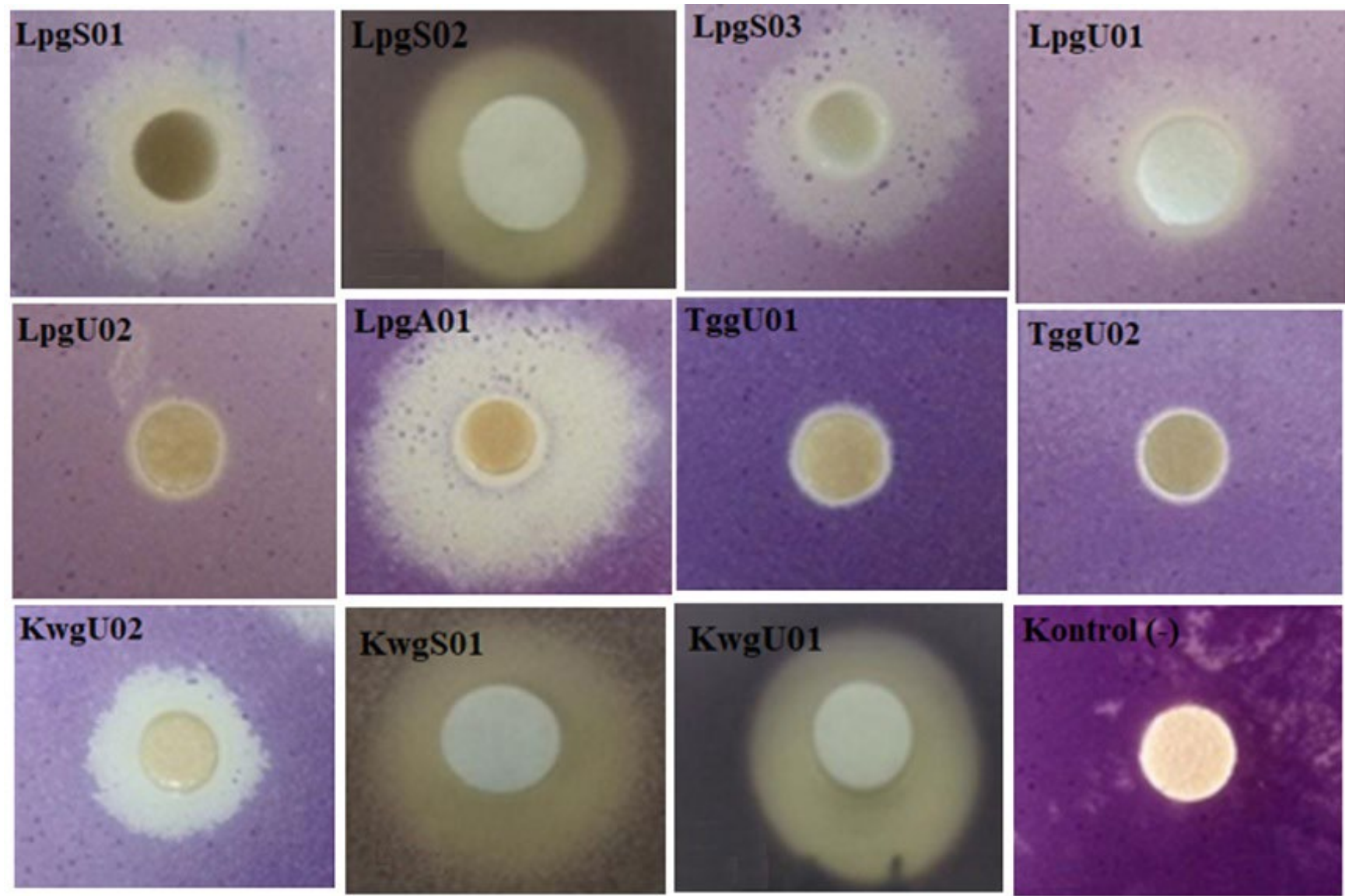

Figure 1. The diameter of the non-purple zone of $C$. violaceum treated with culture supernatants of Bacillus spp. culture supernatant. isolated from samples of shrimp intestines, pond water and pond sediments in several locations of shrimp ponds 
Table 3. Inhibitory activity of violacein accumulation of $C$. violaceum by culture supernatants of Bacillus spp. isolates. The control of violacein accumulation was a single culture of $C$. violaceum without the culture supernatant of Bacillus spp. isolates

\begin{tabular}{|c|c|c|c|c|c|c|}
\hline \multirow[t]{2}{*}{ Isolate code } & \multicolumn{2}{|c|}{$\begin{array}{c}\text { Violacein absorbance } \\
(\lambda 585 \mathrm{~nm}) \text { after incubation }\end{array}$} & \multicolumn{2}{|c|}{$\begin{array}{c}\text { Cells absorbance } \\
(\lambda 660 \mathrm{~nm}) \text { after incubation }\end{array}$} & \multicolumn{2}{|c|}{$\begin{array}{c}\text { Cells absorbance } \\
(\lambda 660 \mathrm{~nm}) \text { after incubation }\end{array}$} \\
\hline & $24 \mathrm{~h}$ & $48 \mathrm{~h}$ & $24 \mathrm{~h}$ & $48 \mathrm{~h}$ & $24 \mathrm{~h}$ & $48 \mathrm{~h}$ \\
\hline$\overline{\mathrm{LpgS01}}$ & 0.072 & 0.149 & 0.963 & 1.480 & 0.075 & 0.100 \\
\hline LpgSO2 & 0.076 & 0.142 & 0.962 & 0.792 & 0.079 & 0.179 \\
\hline LpgS03 & 0.073 & 0.156 & 1.594 & 2.029 & 0.077 & 0.107 \\
\hline LpgU01 & 0.028 & 0.041 & 0.951 & 1.454 & 0.025 & 0.026 \\
\hline LpgU02 & 0.106 & 0.268 & 1.105 & 1.557 & 0.133 & 0.286 \\
\hline LpgA01 & 0.122 & 0.346 & 0.793 & 1.003 & 0.156 & 0.335 \\
\hline TggU01 & 0.133 & 0.631 & 0.780 & 1.034 & 0.166 & 0.567 \\
\hline TggU02 & 0.133 & 0.478 & 0.799 & 1.112 & 0.136 & 0.333 \\
\hline KwgU02 & 0.062 & 0.137 & 0.983 & 1.434 & 0.069 & 0.116 \\
\hline KwgS01 & 0.162 & 0.581 & 0.890 & 1.183 & 0.146 & 0.339 \\
\hline KwgU01 & 0.086 & 0.136 & 0.989 & 0.982 & 0.087 & 0.138 \\
\hline Control (-) & 0.624 & 1.673 & 1.56 & 2.041 & 0.400 & 0.820 \\
\hline
\end{tabular}

Table 4. Percentage of inhibition of violacein pigment formation in C. violaceum per unit index treated with culture supernatant of Bacillus spp. isolates

\begin{tabular}{lcc}
\hline Isolate code & Inhibition percentage of violacein formation per unit index (\%) on incubation: \\
\cline { 2 - 3 } & $24 \mathrm{~h}$ & $48 \mathrm{~h}$ \\
\hline LpgU01 & 93.8 & 96.8 \\
LpgS01 & 81.3 & 87.8 \\
LpgS03 & 80.8 & 87.0 \\
KwgU02 & 82.8 & 85.9 \\
KwgU01 & 78.3 & 83.2 \\
LpgS02 & 80.3 & 78.2 \\
LpgU02 & 66.8 & 65.1 \\
TggU02 & 66.0 & 59.4 \\
LpgA01 & 61.0 & 59.1 \\
KwgS01 & 63.5 & 58.7 \\
TggU01 & 585 & 30.9 \\
\hline
\end{tabular}

Table 5. The bacterial species similarity of the selected isolates base on 16S rDNA genes analysed using the Basic Local Alignment Search Tool-Nucleotide (BLAST-N) in the the National Center for Biotechnology Information (NCBI) Gene Bank website [www.ncbi.nlm.nih.gov]

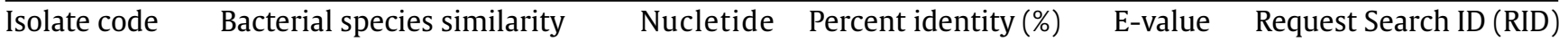
leght ratio of similar/ alignment

(bp)

\begin{tabular}{llllll}
\hline LpgS01 & Bacillus thuringiensis BRAW PT & $1213 / 1227$ & 98.86 & 0 & MUD5EZJW013 \\
LpgS02 & Bacillus velezensis HSB1 & $998 / 999$ & 99.90 & 0 & MUE81J8H013 \\
LpgS03 & Bacillus cereus B10 & $1254 / 1254$ & 100 & 0 & MUF7K4ZT016 \\
LpgU01 & Bacillus cereus ATCC 14579 & $1225 / 1248$ & 98.16 & 0 & MUGOP6TR013 \\
LpgU02 & Bacillus cereus B10 & $1244 / 1266$ & 98.26 & 0 & MUGMCKXB016 \\
LpgA01 & Bacillus cereus EM6 & $1255 / 1258$ & 99.76 & 0 & MUH5HGTE013 \\
TggU01 & Bacillus thuringiensis BRAW PT & $1252 / 1259$ & 99.44 & 0 & MUHJKGU1016 \\
TggU02 & Bacillus sp. hb10 & $1247 / 1256$ & 99.28 & 0 & MUJ0J6V5016 \\
KwgU02 & Bacillus subtilis H1 & $1253 / 1264$ & 99.13 & 0 & MUJAV3TB013 \\
KwgS01 & Bacillus subtilis TW3 & $1191 / 1222$ & 97.46 & 0 & MUJRSN21013 \\
KwgU01 & Bacillus coagulans BSCB 2 & $1329 / 1332$ & 99.77 & 0 & MUK8GD3J013 \\
\hline
\end{tabular}


with Bacillus cereus, two isolates (KwgU02 and KwgS01 isolates) had similarity with Bacillus subtilis, two isolates (LpgS01 and TggU01 isolates) had similarity with Bacillus thuringiensis, and one isolate had similarity with Bacillus coagulan (KwgU01 isolate) and Bacillus velezensis (LpgS02 isolate), respectively. However, based on the phylogenetics tree, the bacterial isolates were clustered in two groups. The LPGSO2 and KWGU02 isolates were separated in different cluster that that of the other isolates (Figure 2).

Molecular analysis using a PCR machine showed that the eleven selected isolates had the aiiA gene encoding AHL lactonase enzymes. The electrophoresis gel agarose of the all-isolate's PCR products showed DNA bands size of $800 \mathrm{bp}$ (Figure 3 ). The BLAST-X analysis of the PCR products sequences confirmed that the all sequences had similarity 97$100 \%$ with $\mathrm{N}$-acyl homoserine lactonase of Bacillus group (Table 6). The analysis showed that almost all isolates had aiiA genes that similar to that of Bacillus cereus. Additionally, the aiiA gene of LpgS01 was similar to Bacillus thuringiensis serovar aizawai. The BLAST-X results also showed that KwgU02 isolate had the lowest similarity value (97\%) to the Bacillus cereus AiiA sequences, while the other isolates had similarity between $99-100 \%$.

\section{Discussion}

The isolation results showed that the obtained isolates that had AQS activity were from shrimp intestine samples, namely 6 isolates and followed by sediment samples as many as 4 isolates. Meanwhile, only one isolate of Bacillus spp. with AQS activity was isolated form pond water samples. The AQS activity was determine by the non-purple zone on an agar plate of $C$. violaceum cultures. The non-purple zone was formed due to the presence of AQS activity which could inhibit $C$. violaceum in producing violacein pigment. The use of this bacterium as an AQS activity test is relatively easy to observe because the contras of purple color violacein pigment. And the violacein formation in C. violaceum is controlled by the quorum sensing (QS) mechanism. The inhibition of violacein formation is an indication of a failure induction of genes expression that responsible for the pigment production due to AQS activity (Hoshino 2011). Therefore, $C$. violaceum bacterium is widely used as a test bacterium to screen bacteria that have AQS activity (Chu et al. 2010; Romero et al. 2011; Novita et al. 2015; Oh et al. 2017). Production violacein pigment production in $C$. violaceum is influenced by
AHL concentration as an autoinducer to induce gene targets expression involved in production of violacein pigment. Romero et al. (2011) reported that the percentage of bacteria that had AQS activity obtained from sediment samples was more than that of pond water samples. While Defoirdt et al. (2011) and Vinoj et al. (2014) reported that Bacillus spp. isolated from the intestine samples of $P$. vannamei was able to AHL.

The supernatants from the eleven selected Bacillus isolates were suspected to synthesize enzymes that can degrade AHL so that the degraded AHL compounds cannot form complexes with regulatory proteins that can induce the expression of genes that responsible for the formation of violacein pigment. There were six Bacillus isolates could inhibit pigment production per index unit with the inhibition percentage more than 75\%, namely LpgS01, LpgS02, LpgS03, LpgU01, LpgU02, and LpgA01 isolates. The enzyme will inactivate of the expression of the vioABCD operon (Stauff and Bassler 2011). AHL compounds regulate the expression of the genes related to the production of violacein pigments (Blosser and Gray 2000). The mutant of $C$. violaceum CVOblu in a gene that responsible for synthesizing AHL, cannot produce AHL so that it cannot produce the pigment violacein. However, with addition of AHL compounds extracted from $V$. fisheri and wild strains of $C$. violaceum, the mutant strain of $C$. violaceum CVOblu was able to re-synthesize the violacein pigment (Blosser and Gray 2000). The decrease in violacein levels together with the decrease in the absorbance value at $600 \mathrm{~nm}$ indicated that the isolates also produced antimicrobial compounds, in addition to producing AHL-degrading enzymes. Antimicrobial compounds such as antibiotics can inhibit the growth of bacteria (Nagorska et al. 2007). In contrast to the activity of antimicrobial compounds, the AQS mechanism does not inhibit the growth or kill bacterial cells, but only inhibits the synthesis of the violacein pigment.

Measurement of violacein pigment production by $C$. violaceum can be calculated based on the violacein units formed during the bacterial growth phase (Chaudhari et al. 2018). The violacein pigment is synthesized from tryptophan substrate by enzymes resulting from the expression of the vioABCD operon (Stauff and Bassler 2011). Violacein pigment production is positively regulated by AHL (Devescovi et al. 2011; Stauff and Bassler 2011). And differences in pigmentation violacein levels of C. violaceum produced in culture can be quantified photometrically (Chaudhariet al.2018). AQS activity of 


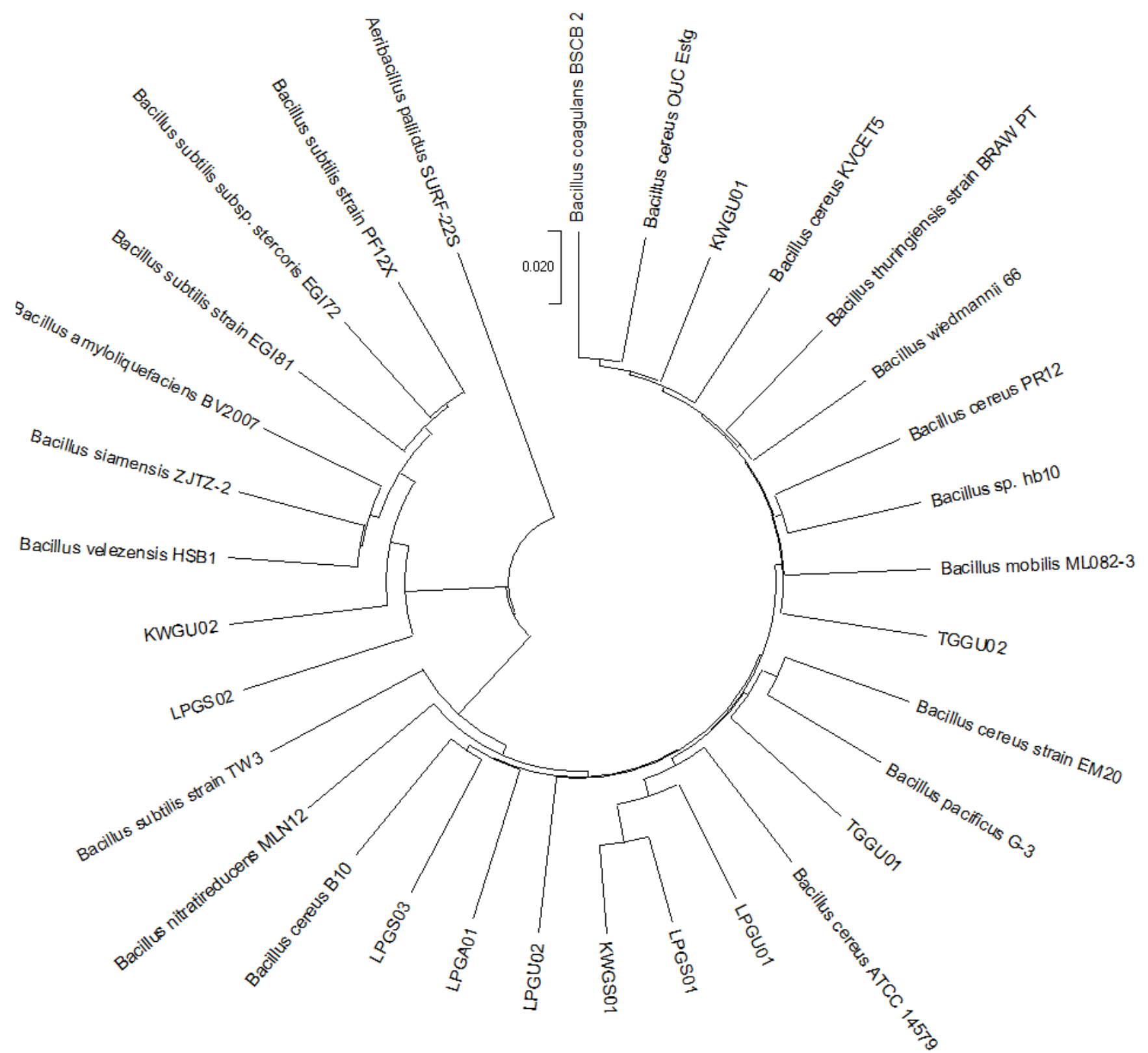

Figure 2. The phylogenetics tree of the 16S rDNA genes of the selected bacterial isolates isolated from shrimp ponds that showing anti-qourum sensing activity. The tree was construted using the maximum likelihood method with $1,000 \mathrm{x}$ bootstraps of the MEGA X software

the six cultures supernatant Bacillus spp. isolates was shown that the Bacillus spp. isolates AHL degrading enzymes, possibly AHL-lactonase enzyme. These six Bacillus spp. isolates have potential to be develop as a bacterial control to inhibit shrimp AHNPD diseases.

The BLAST-N analysis of 165 rDNA gene sequences indicated that all selected isolates were Bacillus spp. The six potential isolates that had high AQS were Bacillus cereus (LpgS03, LpgU01, LpgU02, and LpgA01 isolates), Bacillus thuringiensis (LpgS01 isolate), and
Bacillus velezensis (LpgS02 isolate), respectively. Hagstrom et al. (2002) stated that isolates that had 16S rRNA sequence similarities more than $97 \%$ could represent the same species, while sequence similarities between 93-97\% could represent the identity of bacteria at the genus level but different species. These isolates were confirmed to have the aiiA genes. The aiiA gene is one of the genes encoding AHL lactonase which was detected in the Bacillus spp. group (Chen et al. 2013). AHL lactonase is also encoded 


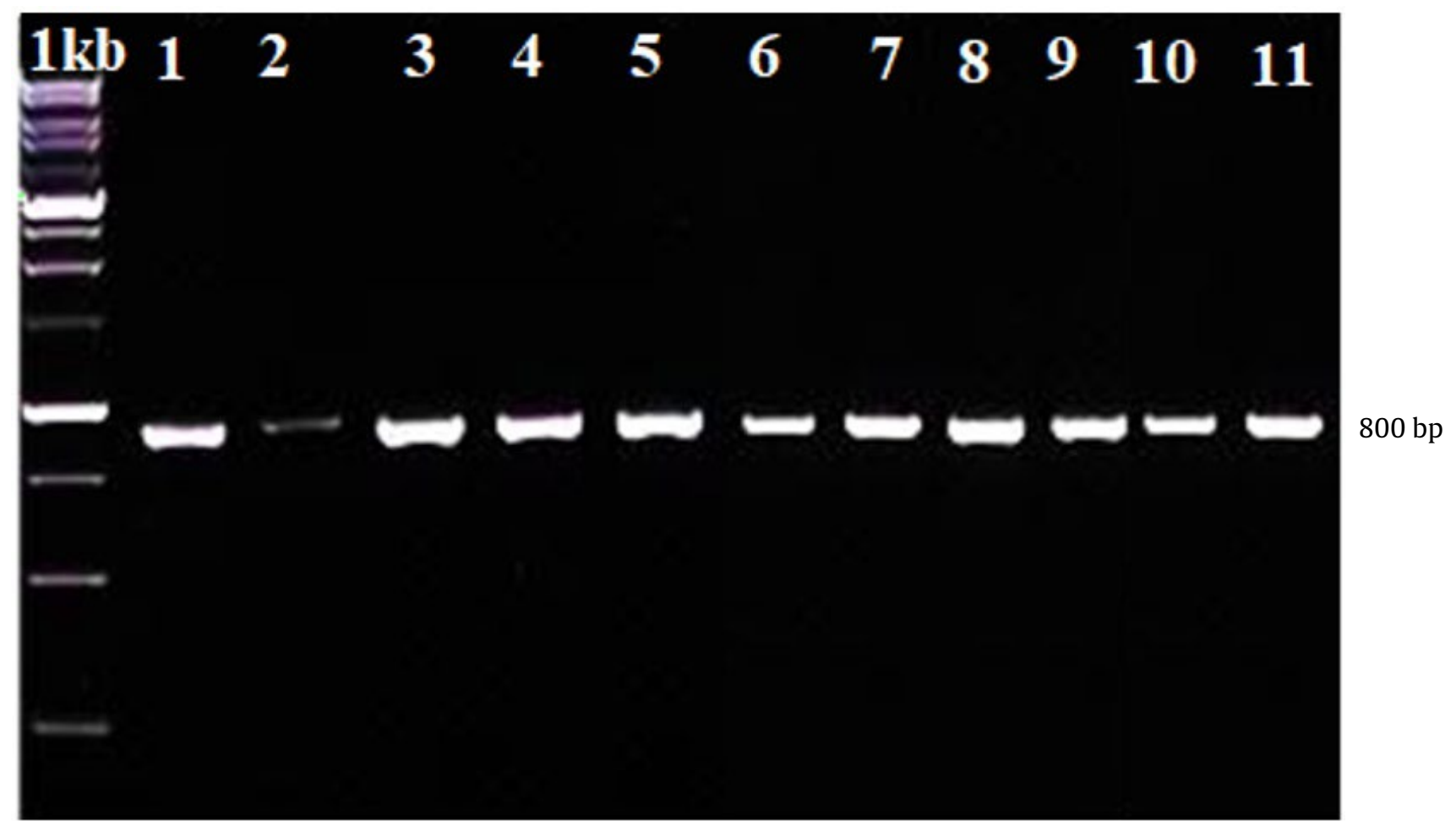

Figure 3. The amplicons 800 bp of aiiA genes of the eleven selected isolates using specific primers of aiiAF and aiiAR visualised on $0.8 \%$ agarose. Simbols and number indicate as follow; M = Marker $1 \mathrm{~kb}, 1=\mathrm{LpgS01}$ isolate, $2=$ LpgS02 isolate, 3 = LpgS03 isolate, $4=\mathrm{LpgU01}$ isolate, 5 = LpgU02 isolate, $6=\mathrm{LpgA01}$ isolate, $7=$ TggU01 isolate, 8 = TggU02 isolate, 9 = KwgS02 isolate, 10 = KwgS01 isolate, and 11 = KwgU01 isolate, respectively

Table 6. The Basic Local Alignment Search Tool-Nucleotide translation protein (BLAST-X) of the aiiA gene amplicon sequences of the eleven selected isolates isolated from shimp ponds

\begin{tabular}{|c|c|c|c|c|c|c|}
\hline Isolate code & Bacterial species similarity & $\begin{array}{l}\text { Maximun } \\
\text { Score (bits) }\end{array}$ & $\begin{array}{l}\text { Amino } \\
\text { acid ratio } \\
\text { of similar/ } \\
\text { alignment }\end{array}$ & $\begin{array}{c}\text { Percent } \\
\text { identity }(\%)\end{array}$ & E-value & Request Search ID (RID) \\
\hline LpgS01 & $\begin{array}{l}\text { AHL lactonase [Bacillus } \\
\text { thuringiensis serovar aizawai] }\end{array}$ & 506 & $246 / 247$ & 99.19 & 0 & MVH8EFST013 \\
\hline LpgS02 & $\begin{array}{l}\mathrm{N} \text {-acyl homoserine lactonase } \\
\text { family protein [Bacillus cereus] }\end{array}$ & 507 & $246 / 247$ & 99.6 & 0 & MVHYY4VS016 \\
\hline LpgS03 & $\begin{array}{l}\mathrm{N} \text {-acyl homoserine lactonase } \\
\text { family protein [Bacillus cereus] }\end{array}$ & 506 & $246 / 247$ & 100.0 & 0 & MVJDBYTJ013 \\
\hline LpgU01 & $\begin{array}{l}\mathrm{N} \text {-acyl homoserine lactonase } \\
\text { family protein [Bacillus cereus] }\end{array}$ & 506 & $246 / 247$ & 99.6 & 0 & MVJX904C016 \\
\hline LpgU02 & $\begin{array}{l}\mathrm{N} \text {-acyl homoserine lactonase } \\
\text { family protein [Bacillus cereus] }\end{array}$ & 506 & $246 / 247$ & 99.6 & 0 & MVK5W0P3013 \\
\hline LpgA01 & $\begin{array}{l}\mathrm{N} \text {-acyl homoserine lactonase } \\
\text { family protein [Bacillus cereus] }\end{array}$ & 506 & $246 / 247$ & 99.6 & 0 & MVKFXY1T013 \\
\hline TggU01 & $\begin{array}{l}\mathrm{N} \text {-acyl homoserine lactonase } \\
\text { family protein [Bacillus cereus] }\end{array}$ & 506 & $246 / 247$ & 99.6 & 0 & MVKNUZKA013 \\
\hline TggU02 & $\begin{array}{l}\mathrm{N} \text {-acyl homoserine lactonase } \\
\text { family protein [Bacillus cereus] }\end{array}$ & 506 & $246 / 247$ & 99.6 & 0 & MVM118FH016 \\
\hline KwgU02 & $\begin{array}{l}\mathrm{N} \text {-acyl homoserine lactonase } \\
\text { family protein [Bacillus cereus] }\end{array}$ & 494 & $240 / 247$ & 97.17 & $6 e-176$ & MVM6TPH5016 \\
\hline KwgS01 & $\begin{array}{l}\mathrm{N} \text {-acyl homoserine lactone } \\
\text { lactonase [Bacillus cereus] }\end{array}$ & 490 & $238 / 240$ & 99.17 & $9 e-175$ & MVMNFNXY013 \\
\hline KwgU01 & $\begin{array}{l}\mathrm{N} \text {-acyl homoserine lactonase } \\
\text { family protein [Bacillus] }\end{array}$ & 451 & $219 / 220$ & 99.55 & 1e-159 & MVNJ1X2F016 \\
\hline
\end{tabular}


by the attM genes (Agrobacterium tumefaciens), ahlD genes (Arthrobacter sp.), qsdA genes (Rhodococcus erythropolis), AhlK genes (Klebsiella pneumoniae) and aiiM genes (Microbacterium testaceum) (Chen et al. 2013).

The amino acid sequences of the AHL lactonase the isolates usually have a conserved motif, namely 107HxHxDH112. This motif is a characteristic of the metal- $\beta$-lactamase superfamily enzymes (Dong et al. 2002; Chen et al. 2013; Rusmana et al. 2017). The enzyme is composed of $\mathrm{Zn}^{2+}$ ions bound to histidine and aspartate ligands (Rusmana et al. 2017). This motif was found in AiiA, AttM, AhlD proteins but not in AiiM (Wang et al. 2010). The AiiA proteins belong to the metallo-hydrolase-like metallod- $\beta$-lactamase superfamily. Metallo hydrolase is a hydrolytic enzyme that performs various biological functions, one of which is AHL lactonase which acts as a catalyst for hydrolysis of ester bonds at the opening of the AHL lactone ring so that the structure changes to acyl homoserine (Chen et al. 2013).

In summary, this study successfully characterized six isolates of Bacillus spp. isolated from shrimp ponds that had high anti-quorum sensing activity to inhibit the pigment production in C. violaceum. The selected isolates had inhibition AQS activity up to $75 \%$. The isolates were identified as Bacillus cereus (four isolates), Bacillus thuringiensis (one isolate), and Bacillus velezensis (one isolate), respectively. The molecular analysis had confirmed that the isolates have aiiA genes encoding AHL-lactonase enzyme. These Bacillus isolates have potential application for controlling AHNPD disease by anti-quorum sensing mechanisms.

\section{Acknowledgements}

This research is funded by Basic Research Grant 2021 of The Directorate HigherEducation, The Ministry of Education, Culture, Research and Technology, Indonesia to IR (contract no: 1/E1/KP.PTNBH/2021).

\section{References}

Blosser, R.S., Gray, K.M., 2000. Extraction of violacein from Chromobacterium violaceum provides a new quantitative bioassay for $\mathrm{N}$-acyl homoserine lactone autoinducers. J Microbiol Methods. 40, 47-55.

Cao, Y., He, S., Zhou, Z., Zhang, M., Mao, W., Zhang, H., Yao, B., 2012. Orally administered thermostable N-acyl homoserine lactonase from Bacillus sp. strain AI96 attenuates Aeromonas hydrophila infection in zebrafish. Appl Environ Microbiol. 78, 1899-1908.
Chen, F., Gao, Y., Chen, X., Yu, Z., Li, X., 2013. Quorum quenching enzymes and their application in degrading signal molecules to block quorum sensing-dependent infection. International journal of molecular sciences. 14, 17477-17500. DOI:10.3390/ijms140917477

Chaudhari, V., Gosai, H., Raval, S., Kothari, V., 2018. Effect of certain natural products and organic solvents on quorum sensing in Chromobacterium violaceum. Asian Pac. J. Trop. Med. 7, 204-211.

Chu, W., Lu, F., Zhu, W., Kang, C., 2010. Isolation and characterization of new potential probiotic bacteria based on quorum-sensing system. J. Appl. Microbiol. $110,202-208$.

Chu, W., Lu, F., Zhu, W., Kang, C., 2010. Isolation and characterization of new potential probiotic bacteria based on quorum-sensing system. J. Appl. Microbiol. $110,202-208$

de la Peña, L.D., Cabillon, N.A., Catedral, D.D., Amar, E.C., Usero, R.C., Monotilla, W.D., Calpe, A.T., Fernandez, D.D., Saloma, C.P., 2015. Acute hepatopancreatic necrosis disease (AHPND) outbreaks in Penaeus vannamei and $P$. monodon cultured in the Philippines. Dis. Aquat. Organ. 116, 251-254. DOI:10.3354/dao02919

De Schryver, P., Defoirdt, T., Patrick Sorgeloos, P., 2014. Early mortality syndrome outbreaks: a microbial management issue in shrimp farming. PLoS Pathog. 10, e1003919. DOI:10.1371/journal.ppat.1003919

Defoirdt. T., Boon, N., Sorgeloos, P., Verstraete, W., Bossier, P., 2008. Quorum sensing and quorum quenching in Vibrio harveyi: lessons learned from in vivo work. ISME Journal. 2, 19-26.

Defoirdt, T., Boon, N., Bossier, P., Verstraete, W., 2004. Disruption of bacterial quorum sensing: an unexplored strategy to fight infections in aquaculture. Aquaculture. 240, 69-88.

Defoirdt, T., Boon, N., Sorgeloos, P., Verstraete, W., Bossier, P., 2008. Quorum sensing and quorum quenching in Vibrio harveyi: lessons learned from in vivo work. ISME Journal. 2, 19-26.

Delshad, St., Soltanian, S., Sharifiyazdi, H., Bossier, P., 2018. Effect of quorum quenching bacteria on growth, virulence factors and biofilm formation of Yersinia ruckeri in vitro and an in vivo evaluation of their probiotic effect in rainbow trout. J. Fish. Dis. 41, 1-10.

Dong, Y., Gusti, A.R., Zhang, Q., Xu, J., Zhang, L., 2002. Identification of quorum-quenching $\mathrm{N}$-acyl homoserine lactonases from Bacillus species. Appl Environ Microbiol. 68, 1754-1759.

[FAO] Food and Agriculture Organization. 2013. Report of the FAO/MARD Technical Workshop on Early Mortality Syndrome (EMS) or Acute Hepatopancreatic Necrosis Syndrome (AHPND) of Cultured Shrimp (under TCP VIE/3304). Hanoi, Viet Nam, 25-27 June 2013. FAO Fisheries and Aquaculture Report No. 1053. Rome. pp. 54.

[GAA] Global Aliance Aquaculture. 2013. Cause of EMS shrimp disease identified. GAA News Releases. Available at: http://www.gaalliance.org/newsroom. [Date accessed: 20 October 2020]

Hagström, A., Pommier, T., Rohwer, F., Simu, K., Stolte, W. Svensson, D., Zweifel, U. L., 2002. Use of 16 S ribosomal DNA for delineation of marine bacterioplankton species. Applied and environmental microbiology. 68 3628-3633. DOI:10.1128/AEM.68.7.3628-3633.2002

Han, J.E., Tang, K.F.J., Lightner, D.V., 2015. Genotyping of the virulence plasmid harbored in the Vibrio parahaemolyticus isolates causing acute hepatopancreatic necrosis disease (AHPND) in shrimp. Dis. Aquat. Organ. 115, 245-251. 
Han, J.E., Tang, K.FJ. Lightner, D.V Tran, L 2015. Photorhabdus insect related (Pir) toxin-like genes in a plasmid of Vibrio parahaemolyticus. The causative agent of acute hepatopancreatic necrosis disease (AHPND) of shrimp. Dis. Aquat. Organ. 113, 33-40.

Hoshino, T., 2011. Violacein and related tryptophan metabolites produced by Chromobacterium violaceum: biosynthetic mechanism and pathway for construction of violacein core. Applied Microbiology and Biotechnology. 91, 1463-1475. DOI:10.1007| s00253-011-3468-z

Kalia, V.C., 2013. Quorum sensing inhibitors: an overview. Biotechnol Adv. 31, 224-245.

Lee, C.T., Chen, I.T., Yang, Y.T., Ko, T.P., Huang, Y.T., Huang, J.Y., Huang, M.F., Lin, S.J., Chen, C.Y., Lin, S.S., 2015. The opportunistic marine pathogen Vibrio parahaemolyticus becomes virulent by acquiring a plasmid that expresses a deadly toxin. Proc Natl Acad Sci. 112, 10798-10803,

Longyant, S., Rukpratanporn, S., Chaivisuthangkura, Suksawad, P., Srisuk, C., Sithigorngul, W., Piyatiratitivorakul, S., Sithigorngul, P., 2008. Identification of Vibrio spp. in vibriosis Penaeus vannamei using developed monoclonal antibodies. J. Invertebr. Pathol. 98, 63-68.

McClean, K.H., Winsonet, M.K., Fish, L., Taylor, A., Chhabra, S.R., Camara, M., Daykin, M., Lamb, J.H., Swift, A., Bycroft, B.W. 1997. Quorum sensing and Chromobacterium violaceum: exploitation of violacein production and inhibition for the detection of $\mathrm{N}$-acylhomoserine lactones. Microbiol. 143, 3703-3711.

Morohoshi, T., Kato, M., Fukamachi, K., Kato, N., Ikeda, T., 2008. N -Acylhomoserine lactone regulates violacein production in Chromobacterium violaceum type strain ATCC12472. FEMS Microbiol Lett. 279, 124-130.

Nagorska, K., Bikowski, M., Obuchowski, M., 2007. Multicellular behaviour and production of a wide variety of toxic substances support usage of Bacillus subtilis as a powerful biocontrol agent. Acta Biochim Pol. 54:495-508.

Natrah, F.M.I., Defoirdt, T., Sorgeloos, P., Bossier, P., 2011. Disruption of bacterial cell-to-cell communication by marine organisms and its relevance to aquaculture. Mar. Biotechnol. 13, 109-126.

Novita, H., Rusmana, I., Yuhana, M., Pasaribu, F.H., 2015. Potential of Bacillus sp. as a producer of AHL lactonase and its application as a probiotic for the prevention of MAS in catfish (Clarias gariepinus). J. Fish. Aquat. Sci. 10, 464-476.

Novita, H., Rusmana, I., Yuhana, M., Pasaribu, F.H., 2015. Potential of Bacillus sp. as a producer of AHL lactonase and its application as a probiotic for the prevention of MAS in catfish (Clarias gariepinus). J. Fish. Aquat. Sci. 10, 464-476.

Oh, H.S., Tan, C.H., Low, J.H., Rzechowicz, M., Siddiqui, M.F., Winters, H., Kjelleberg, S., Fane, A.G., Rice, S.A., 2017. Quorum quenching bacteria can be used to inhibit the biofouling of reverse osmosis membranes. Water Res. 112, 29-37.

Romero, M., Martin-Cuadrado, A.B., Roca-Rivada, A., Cabello, A.M., Otero, A., 2011. Quorum quenching in cultivable bacteria from dense marine coastal microbial communities. FEMS. Microbiol. Ecol. 75, 205-217.
Romero, M., Muras, A., Mayer, C., Bujan, N., Magarinos, B., Otero, A., 2014. In vitro quenching of fish pathogen Edwardsiella tarda AHL production using marine bacterium Tenacibaculum sp. strain 20J cell extracts. Dis. Aquat. Organ. 108, 217-225.

Rusmana, I., Asmarany, A., Wahyudi, A.T., 2017. Cloning and expression of acyl homoserine lactone (AHL) lactonase genes of Bacillus cereus INT1c and Bacillus thuringiensis SGT3g in Escherichia coli. African Journal of Biotechnology 16, 1895-1901. DOI:10.5897/ AJB2017.16200

Sarjito, Haditomo, A.H.C., Desrina, Djunaedi, Prayitno, S.B., 2018. The diversity of vibrios associated with vibriosis in Pacific White Shrimp (Litopenaeus vannamei) from extensive shrimp pond in Kendal District, Indonesia. In: 3rd International Conference on Tropical and Coastal Region Eco Development 2017; 2017 Okt 2-4; Yogyakarta, Indonesia. Yogyakarta: IOP Science. 116:012011.1-012011.7.

Soto-Rodriguez, S.A., Gomez-Gill, B., Lozano-Olvera, R. Betancourt-Lozano, M., Morales-Coarrubias, M.S., 2015. Field and experimental evidence of Vibrio parahaemolyticus as the causative agent of acute hepatopancreatic necrosis disease of cultured shrimp (Litopenaeus vannamei) in Northwestern Mexico.Appl. Environ. Microbiol. 81, 1689-1699.

Stauff, D.L., Bassler, B.L., 2011. Quorum sensing in Chromobacterium violaceum: DNA recognition and gene regulation by the CviR receptor.J. Bacteriol. 193 , 3871-3878.

Torres, M., Reina, J.C., Fuentes-Monteverde, J.C., Fernandez, G., Rodriguez, J., Jimenez, C., Llamas, I., 2018. AHLlactonase expression in three marine emerging pathogenic Vibrio spp. reduces virulence and mortality in brine shrimp (Artemia salina) and manila clam (Venerupis philippinarum). PLOS ONE 13, 1-23.

Tran, L., Nunan, L., Redman, R.M., Mohney, L.L., Pantoja, C.R., Fitzsimmons, K., Lightner, D.V., 2013. Determination of the infectious nature of the agent of acute hepatopancreatic necrosis syndrome affecting penaeid shrimp. Dis. Aquat. Org. 105, 45-55.

Vinoj, G., Vaseeharan, B., Thomas, S., Spiers, A.J., Shanthi, S., 2014. Quorum-quenching activity of the AHLlactonase from Bacillus licheniformis DAHB1 inhibits Vibrio biofilm formation in vitro and reduces shrimp intestinal colonisation and mortality. Mar. Biotechnol. 16, 707-715.

Wang, W.Z., Morohoshi, T., Ikenoya, M., Someya, N., Ikeda, T., 2010. AiiM, a novel class of $\mathrm{N}$-acylhomoserine lactonase from the leaf-associated bacterium Microbacterium testaceum. Appl Environ Microbiol. 276, 2524-2530. DOI:10.1128/AEM.02738-09

Yuniarti, A., Maftuch, Soemarno, Aulanni'am., 2015. In vitro and in vivo study of acyl homoserine lactone degrading Bacillus against Vibrio harveyi. Int J Biosci. 6, 338-348. 